16. Bonetta, L., Protein-protein interactions: interactome under construction. Nature, 2010, 468(7325), 851.

17. Huo, T., Liu, W., Guo, Y., Yang, C., Lin, J. and Rao, Z., Prediction of host-pathogen protein interactions between Mycobacterium tuberculosis and Homo sapiens using sequence motifs. BMC Bioinformat., 2015, 16(1), 100.

18. Winnenburg, R., Baldwin, T. K., Urban, M., Rawlings, C., Köhler, J. and Hammond-Kosack, K. E., PHI-base: a new database for pathogen host-interactions. Nucleic Acids Res. (suppl. 1), 2006, 34, D459-D464.

19. Xiang, Z., Tian, Y. and He, Y., PHIDIAS: a pathogen-host interaction data integration and analysis system. Genome. Biol., 2007, 8(7), R150.1-R150.15.

20. Wattam, A. R. et al., PATRIC, the bacterial bioinformatics database and analysis resource. Nucleic Acids. Res., 2013, 42(D1), D581-D591.

21. Rapanoel, H. A., Mazandu, G. K. and Mulder, N. J., Predicting and analyzing interactions between Mycobacterium tuberculosis and its human host. PLOS ONE, 2013, 8(7), e67472, 1-4.

22. Zhou, H., Gao, S., Nguyen, N. N., Fan, M., Jin, J., Liu, B. and Wong, L., Stringent homology-based prediction of $H$. sapiens $-M$. tuberculosis H37Rv protein-protein interactions. Biol. Direct, 2014, 9(1), 5, 1-30.

23. Chen, C., Huang, H. and Wu, C. H., Protein bioinformatics databases and resources. In Protein Bioinformatics, Humana Press, New York, USA, 2017, pp. 3-39.

24. Garcia-Garcia, J., Schleker, S., Klein-Seetharaman, J. and Oliva, B., BIPS: BIANA Interolog Prediction Server. A tool for proteinprotein interaction inference. Nucleic Acids Res., 2012, 40(W1), W147-W151.

25. Powell, S. et al., eggNOG v3. 0: orthologous groups covering 1133 organisms at 41 different taxonomic ranges. Nucleic Acids Res., 2011, 40(D1), D284-D289.

26. Walhout, A. J. et al., Protein interaction mapping in C. elegans using proteins involved in vulval development. Science, 2000, 287(5450), 116-122.

27. UniProt Consortium, UniProt: the universal protein knowledgebase. Nucleic Acids Res., 2017, 45(D1), D158-D169.

28. Cohen, T., van Helden, P. D., Wilson, D., Colijn, C., McLaughlin, M. M., Abubakar, I. and Warren, R. M., Mixed-strain Mycobacterium tuberculosis infections and the implications for tuberculosis treatment and control. Clin. Microbiol. Rev., 2012, 25(4), 708719.

Received 5 March 2019; revised accepted 9 September 2019

doi: $10.18520 / \mathrm{cs} / \mathrm{v} 118 / \mathrm{i} 2 / 292-297$

\section{Effect of storage conditions on vermicompost quality}

\author{
Pankaj Kumar ${ }^{1,2, *}$, Pawan Sharma ${ }^{3}$, \\ Tilak Ranjan Kumar ${ }^{1}$, H. C. Sharma ${ }^{3}$ and \\ R. C. Dubey ${ }^{4}$
}

${ }^{1}$ Department of Microbiology, Dolphin (PG) College of Science and Agriculture Chunnikalan, Fatehgarh Sahib 140 307, India

${ }^{2}$ Department of Microbiology, Dolphin (PG)

Institute of Biomedical and Natural Sciences, Manduwala, Dehradun 248 007, India

${ }^{3}$ ICAR-Indian Institute of Soil and Water Conservation, Chandigarh 160019 , India

${ }^{4}$ Department of Botany and Microbiology,

Gurukul Kangri Vishwavidyalaya, Haridwar 249 404, India

To study the effects of storage conditions on vermicompost, an experiment was conducted with freshly prepared, un-dried fresh vermicompost $(60 \%$ moisture), and pre-air dried vermicompost (30\% moisture) stored in polythene bags for a period of four weeks under different moisture and aeration conditions. Three different storage conditions were tested by placing fresh and pre-dried vermicompost in: (1) open bags, (2) holed bags and (3) sealed bags. Vermicompost properties were analysed weekly for four weeks after storage. The moisture content declined in both fresh and pre-dried vermicompost, with a maximum decline under open bag condition, followed by holed and sealed bags. In the sealed airtight bags with fresh vermicompost, a rapid decline in total organic carbon, nitrogen and electrical conductivity was observed during the first and second week of storage, possibly due to microbially-triggered volatilization losses. However, such decline was lacking in pre-dried vermicompost. In open and holed bags, the carbon and nitrogen were retained and rather increased during storage, possibly due to ongoing aerobic decomposition and no volatilization losses. The highest nutrient quality was observed under predried holed bag conditions, possibly due to optimal microbial activity releasing nutrients, combined with no volatilization losses. It was concluded that fresh vermicompost must be air-dried before its storage in bags. Storage of air-dried vermicompost under aerobic conditions using open/ holed bags appears to be the best option for retaining nutrients and quality of vermicompost.

Keywords: Carbon, electrical conductivity, nitrogen, quality, storage conditions, vermicompost.

VERMICOMPOST is widely used as an organic source of nutrients and carbon due to its high availability of nutrients and also for improving soil aeration, waterholding capacity, buffer capacity, and cation exchange capacity of soils ${ }^{1,2}$. Application of agrochemicals for

*For correspondence. (e-mail: guptapankaj23@gmail.com) 

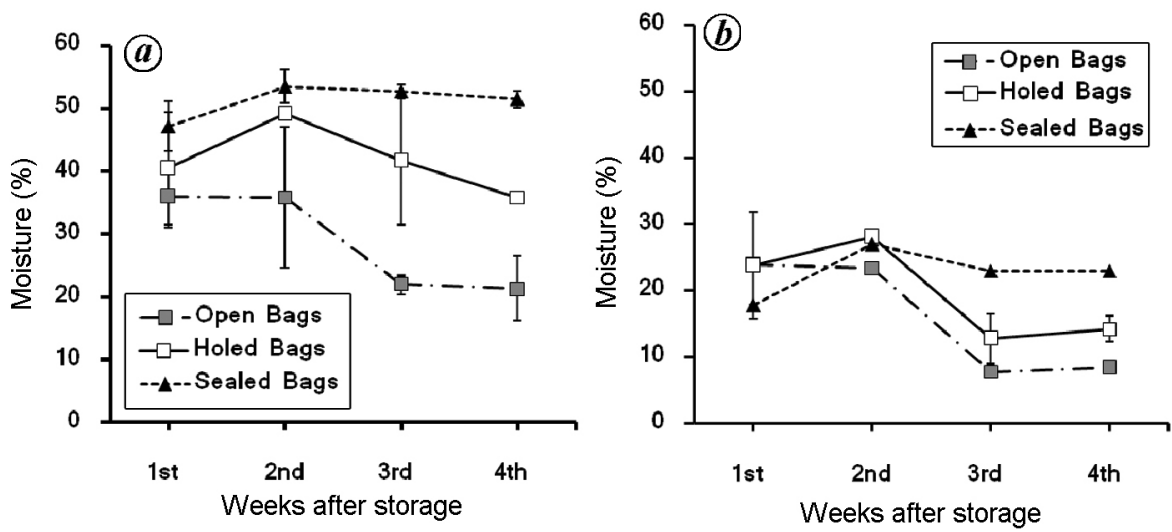

Figure 1. Changes in moisture percentage during storage of fresh vermicompost $(\boldsymbol{a})$ and pre-dried vermicompost (b) stored under different condition of open, holed and sealed polythene bags across storage time. (Bars indicate \pm 1 standard deviation.)
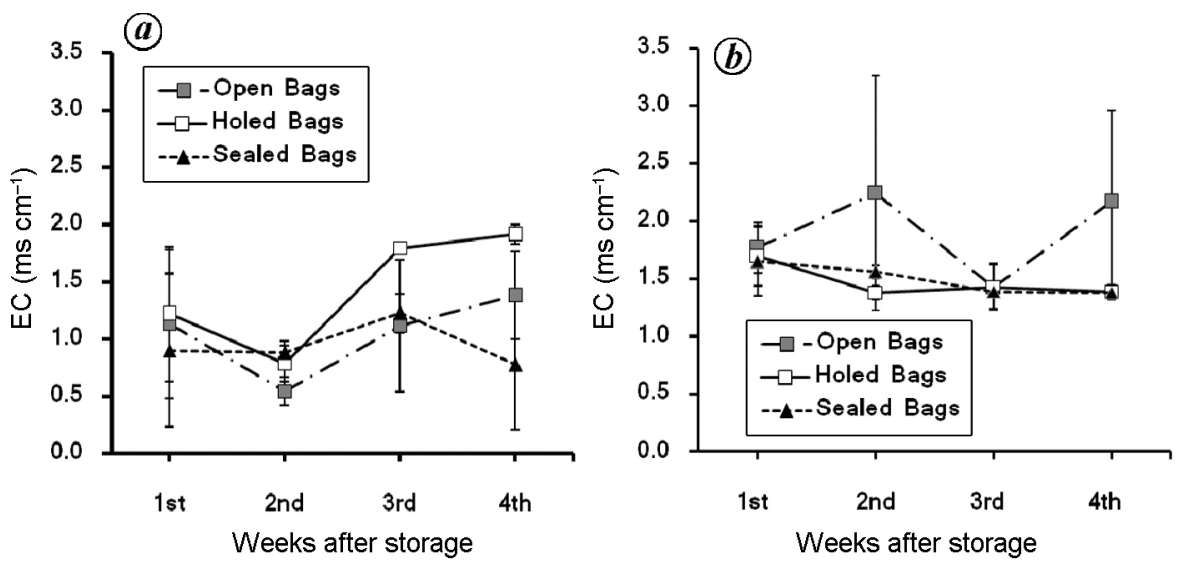

Figure 2. Changes in electrical conductivity during storage of fresh vermicompost $(\boldsymbol{a})$ and pre-dried vermicompost $(\boldsymbol{b})$ stored under different condition of open, holed and sealed polythene bags across different storage time. (Bars indicate \pm 1 standard deviation.)

growth and yield enhancement of crops produce harmful consequences to the environment ${ }^{3}$. Organic farming systems using compost or vermicompost heavily rely on the nutrients of biological origin in the soil. Vermicompost is excreta of earthworms with high amounts of humus, nitrogen $(\mathrm{N})$, phosphorous, potassium, micronutrients and beneficial soil microorganims ${ }^{4,5}$. Previous studies have shown that vermicompost can positively affect soil physical and chemical properties, ${ }^{6,7}$. However, in farmers' fields, vermicompost is stored under a wide range of conditions before its field application. Changes occurring in the nutrient concentration and other qualities of vermicompost during storage are unknown, although a few studies have reported major changes ${ }^{8,9}$. In the present study, we therefore investigated the effects of various storage conditions on vermicompost quality.

The vermicompost used in the present work was generated from cow dung and the epigeic species Eisenia foeti$d a$. The polythene bags used for storage of vermicompost had a capacity of $1 \mathrm{~kg}$, length of $25 \mathrm{~cm}$ and a width of $18 \mathrm{~cm}$. In each bag, $0.5 \mathrm{~kg}$ of vermicompost was stored.
Freshly prepared vermicompost, (A), and vermicompost air-dried for 20 days, (B), were kept at room temperature under different storage treatments: (1) Open bags (bags kept open during storage), (2) Holed bags (bags punched with about 30 holes of $0.3 \mathrm{~mm}$ each all over), and (3) Sealed bags (sealed airtight after adding vermicompost). The six storage treatments of vermicompost were replicated 12 times leading to a total of 72 bags. Every week, three bags of each treatment were taken and analysed for physico-chemical properties and nutrient status. Moisture in the vermicompost was determined by gravimetry. Electrical conductivity (EC) was measured in suspensions of samples in water $(1: 2, \mathrm{w} / \mathrm{v})$ using a EITM 611E EC meter (Elico, Hyderabad, India). Total $\mathrm{N}$ and carbon (C) in vermicompost were analysed by a CHNS Analyzer (Elementar Analysensysteme GmbH, Langenselbold, Germany).

The initial moisture of the storage treatments during week 1 was much higher (30-50\% moisture) in fresh undried vermicompost (A), as compared to the pre-dried vermicompost (B; 20-30\% moisture) (Figure $1 a$ and $b$ ). 

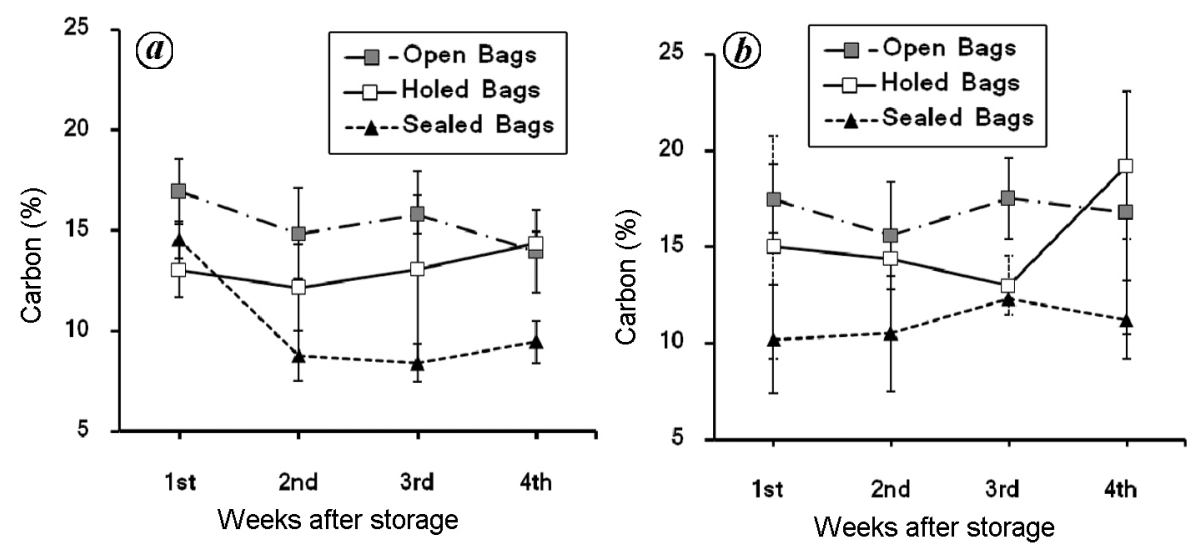

Figure 3. Changes in percentage of carbon during storage of fresh vermicompost (a) and pre-dried vermicompost $(\boldsymbol{b})$ stored under different condition of open, holed and sealed polythene bags across storage time. (Bars indicate \pm 1 standard deviation.)
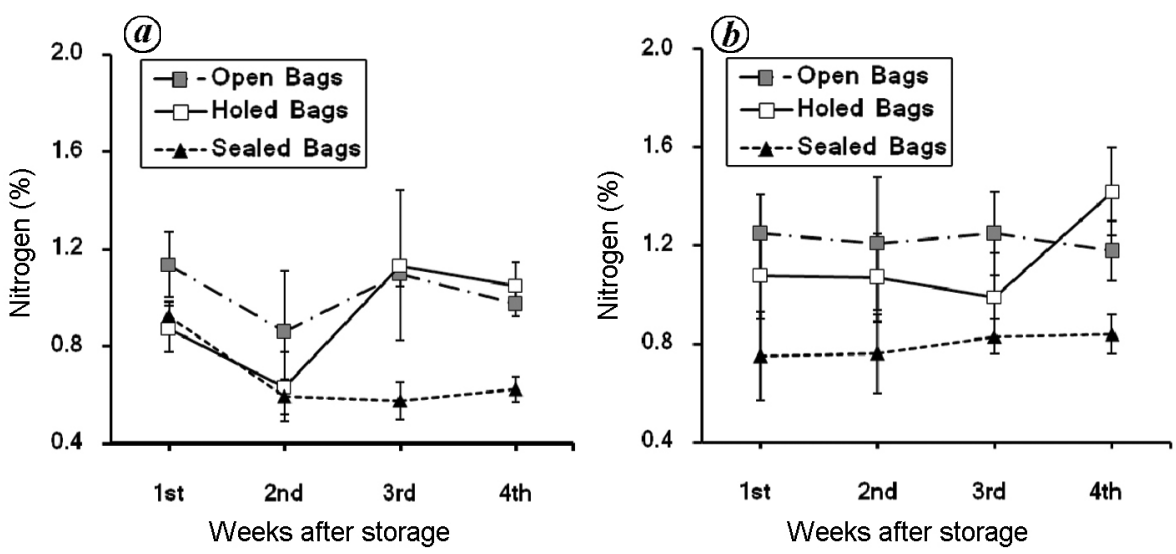

Figure 4. Changes in percentage of nitrogen during storage of fresh vermicompost (a) and pre-dried vermicompost $(\boldsymbol{b})$ stored under different conditions of open, holed and sealed polythene bags across different storage time. (Bars indicate \pm 1 standard deviation.)

There was a sharp decline in moisture in open bags followed by holed bags and sealed bags up to week 3 , which stabilized in week 4. Storage treatments significantly affected the EC until week 2 with the maximum increase in holed bags, which stabilized during the next two weeks. Thus, the EC of vermicompost declined for two weeks across all treatments, but increased in open and holed bags during week 3 and week 4 (Figure $2 a$ and $b$ ). Total organic $\mathrm{C}$ and $\mathrm{N}$ declined significantly in sealed bags with fresh vermicompost (Figures $3 a$ and $4 a$ ), whereas no such decline was observed in sealed bags with dried vermicompost (Figures $3 b$ and $4 b$ ). Organic $\mathrm{C}$ and $\mathrm{N}$ remained stable in holed and open bags during week 2-3 and increased slightly in holed bags during week 4 in both fresh and pre-dried vermicompost (Figures 3 and 4).

The results clearly showed that the moisture and aeration conditions during storage affect vermicompost's quality. The change in EC might reflect the uptake or release of mineral nutrients by microbial activities under higher moisture and aeration as reported earlier ${ }^{10}$. The $\mathrm{C}$ and $\mathrm{N}$ losses under anaerobic conditions in sealed bags may be caused by increased microbe-induced volatilization/denitrification. Such losses have also been reported during composting of farm residues ${ }^{11}$. On the otherhand, increase in $\mathrm{C}$ and $\mathrm{N}$ during storage in holed and open bags may be caused by aerobic decomposition of organic substances and conversion of ammonical nitrogen to nitrates or nitrites due to nitrification and it may improve nutrient quality. Vermicompost is rich in microbial and soil enzyme activities ${ }^{12,13}$ and the moisture, aeration or anaerobic conditions during storage play a major role in maintaining its quality.

In vermicompost, there is a continuous process of $\mathrm{C}$ mineralization, which, under aerobic and moist conditions enhances nutrient release from undecomposed organic matter, whereas under anaerobic conditions leads to $\mathrm{N}$ volatilization losses ${ }^{8,11}$. Therefore fresh vermicompost should be air-dried to reduce microbial activities before its storage. It should be stored under dry and 
aerobic conditions in order to maintain its quality. Long term storage studies should be conducted to investigate the optimum timing and storage conditions of vermicompost for enhanced benefits in field application.

1. Nada, W. M., Van Rensburg, L., Claassens, S. and Blumenstein, O., Effect of vermicompost on soil and plant properties of coal spoil in the Lusatian Region (Eastern Germany). Commun. Soil Sci. Plant Anal., 2011, 42, 1945-1957.

2. Wang, X. X., Zhao, F., Zhang, G., Zhang, Y. and Yang, L., Vermicompost improves tomato yield and quality and the biochemical properties of soils with different tomato planting history in a greenhouse study. Front. Plant Sci., 2017, 8, 1978.

3. Karimi, H., Mokhtari, M., Salehi, F., Sojoudi, S. and Ebrahimi, A., Changes in microbial pathogen dynamics during vermicomposting mixture of cow manure-organic solid waste and cow manure-sewage sludge. Int. J. Recycl. Org. Waste Agric., 2017, 6, $57-61$.

4. Chaoui, H. I., Zibilske, L. M. and Ohnot, Effects of earthworms cast and compost on soil microbial activity and plant nutrient availability. Soil Biol. Biochem., 2003, 35, 295-302.

5. Guerrero, R. D., Vermicompost production and its use for crop production in the Philippines. Int. J. Global Env. Issue., 2010, 10(3/4), 378-383.

6. Rekha, G. S., Kaleena, R. K., Elumalai, D., Srikumaran, M. P. and Maheswari, V. N., Effects of vermicompost and plant growth enhancers on the exo-morphological features of Capsicum annum (Linn.) Hepper. Int. J. Recycl. Org. Waste Agric., 2018, 7(1), $83-88$.

7. Ramnarain, Y. I., Ori, L. and Ansari, A. A., Effect of the use of vermicompost on the plant growth parameters of Pak Choi (Brassica rapa var. chinensis) and on the soil structure in Suriname. J. Global Agric. Ecol., 2018, 8(1), 8-15.

8. Decaens, T., Rangel, A. F., Asakawa, N. and Thomas, R. J., Carbon and nitrogen dynamics in ageing earthworm casts in grasslands of the eastern plains of Colombia. Biol. Fert. Soils, 1999, 30, 20-28.

9. Karthikeyan, M., Gajalakshmi, S. and Abbasi, S. A., Effect of storage on the properties of vermicompost generated from paper waste: with focus on pre drying and extent of sealing. Int. J. Energy Environ. Eng., 2014, 5, 291-301.

10. Harit, A. K., Karthikeyan, M., Gajalakshmi, S. and Abbasi, S. A., Effect of storage on some physical and chemical characteristics of vermicast. J. Appl. Hortic., 2014, 16(2), 112-116.

11. Singh, A. and Sharma, S., Composting of a crop residue through treatment with microorganisms and subsequent vermicomposting. Biores. Technol., 2002, 85, 107-111.

12. Sharma, P., Sharma, H. C., Singh, P. and Prasad, R., Vermicomposts and biofertilizers for improved tomato productivity and soil properties in degraded soils of lower Himalayas. Indian J. Soil Conserv., 2013, 41, 274-278.

13. Tejada, M., Gómez, I., Hernández, T. and García, C., Utilization of vermicomposts in soil restoration: effects on soil biological properties. Soil Sci. Soc. Am. J., 2010, 74, 525-532.

ACKNOWLEDGEMENTS. We are grateful to Director, ICAR-Indian Institute of Soil and Water Conservation, Dehradun for permission to conduct these studies at research centre, Chandigarh. The financial assistance by Dolphin College, Chandigarh is gratefully acknowledged.

Received 11 January 2019; revised accepted 24 September 2019

\section{A comparative study of antioxidant activity and total phenolic content of fresh juices of some common Indian fruits with their commercial counterparts}

\author{
Brototi Roy, Jyoti Singh* and Tanya Dewan \\ Department of Zoology, Maitreyi College, Chanakyapuri, \\ Delhi 110 021, India
}

Oxidative stress caused by overproduction of free radicals has been implicated in the pathogenesis of various chronic diseases like cancer, diabetes, cardiovascular diseases, and neurodegenerative and immunological disorders. Physiologically, these free radicals are scavenged continuously by numerous beneficial substances known as antioxidants. Fruits are rich in antioxidants such as ascorbic acid, flavonoids and polyphenols that strengthen our immunity and help us maintain good health. In recent times, there has been an increasing trend to supplement our diet with packaged fruit juices. In light of this, the present study aims to compare the antioxidant activity and total phenolic content (TPC) of commonly available fresh juices of some fruits found in the Indian subcontinent with their commercial counterparts, available in two popular brands. Folin-Ciocalteu method was used to determine TPC, while ferric reducing antioxidant power assay was performed to evaluate the antioxidant activity of fruit juices. Among fresh juices, the highest antioxidant property and TPC was found in pomegranate followed by litchi. Amongst packed fruit juices, the antioxidant property and TPC was highest in pomegranate and lowest in apple. However, when compared with fresh fruit juices, the antioxidant activity as well as TPC of commercial juices were observed to be significantly less in all cases. These observations prompt serious rethinking on the use of commercial juices as a source of antioxidants.

Keywords: Antioxidant activity, fresh fruits, packaged juices, total phenolic content.

REACTIVE oxygen species are known to cause various types of damages to biological systems leading to many non-communicable diseases ${ }^{1-3}$. Several epidemiological studies as well meta-analysis have revealed the protective effect of fruit juices against cancer, stroke and other noncommunicable diseases that can be related to the antioxidants found in these fruits. These antioxidants play a crucial role in the maintenance of health and prevention of various pathological conditions such as cardiovascular and neurological diseases, age-related disorders, cancer, etc. $^{4-6}$. A report published in 2003 by the World Health

*For correspondence. (e-mail: jyoti@maitreyi.du.ac.in) 